\title{
EFFECT OF FRUITS AND VEGETABLES INTAKE ON OBESITY IN SCHOOL-AGED CHILDREN: META-ANALYSIS
}

\author{
Utami Pangestu'), Yulia Lanti Retno Dewi²), Hanung Prasetya3) \\ 1)Masters Program in Public Health, Universitas Sebelas Maret \\ 2)Department of Nutrition, Faculty of Medicine, Universitas Sebelas Maret \\ 3)Study Program in Acupuncture, Health Polytechnics, Ministry of Health, Surakarta
}

\begin{abstract}
Background: Previous studies suggest that individual and environmental factors were associated lack of vegetable and fruit consumption, which can lead to obesity. Recent studies have indicated the level of vegetable and fruit intake in children aged 2-7 years is particularly low. The purpose of this study was to examine the effect of fruits and vegetables intake on obesity in school-aged children.

Subjects and Method: This was meta-analysis and systematic review. The study was conducted by collecting published articles from Google Scholar, PubMed, Research Gate, dan Springer Link databases, from year 2011 to 2019. Keywords used "Nutrition" OR "Obesity" AND "Cross sectional". The inclusion criteria were full text, using English OR Indonesian language, using cross-sectional study design, and reporting adjusted odds ratio. The study population (P) was school-aged children. Intervention (I) was fruits and vegetables intake with comparison (C) malnutrition. The study outcome (O) was obesity. The collected articles were selected by PRISMA flow chart. The quantitative data were analyzed using Revman 5.3.

Results: 6 studies from Ethiopia, South Afrika, Nepal, Ghana, Saudi Arabia, reported that low fruits and vegetables intake increased the risk of obesity in school-aged children $(\mathrm{aOR}=1.34$; $95 \% \mathrm{CI}=1.06$ to $\left.1.70 ; \mathrm{p}<0.001 ; \mathrm{I}_{2}=92 \%\right)$.

Conclusion: Low fruits and vegetables intake increased the risk of obesity in school-aged children.
\end{abstract}

Keywords: obesity, nutrition, fruits and vegetables intake, school-aged children

\section{Correspondence:}

Utami Pangestu. Masters Program in Public Health, Universitas Sebelas Maret. Jl. Ir. Sutami 36A, Surakarta 57126, Central Java, Indonesia. Email: utamipangestu@gmail.com. Mobile: 087836021638 . 